\title{
Re-visiting the Drivers for Increasing External Debt
}

\author{
Ibrahim Mohammed Adamu \\ Department of Economics, Faculty of Social Sciences, Bayero University, Kano, Nigeria \\ imadamu.eco@buk.edu.ng \\ DOI: https://doi.org/10.37134/jcit.vo19.5.2019
}

\begin{abstract}
This paper investigates the drives for increasing external debt in an open economy Nigeria over the period 1970 to 2017 using general to specific approach (GETS) approach (Hendry, 1995). The Johansen cointegration test confirms that variables have long run relationship. The empirical results for both long run and short run estimates indicate oil price, domestic savings and fiscal deficits play a significant role in increasing external debt in Nigeria. The study also found evidence that the dummy variables for exchange rate and debt relief also accelerate the growth of external. This finding indicates that, after the multilateral debt relief between 2005 and 2006, fresh loans are still coming to Nigeria. To this end, Nigeria should focus on investment in real sectors especially in agriculture and manufacturing to increase export performance. This would enable the country to generate adequate foreign earnings and stimulate domestic savings, and reduce reliance on oil revenue.
\end{abstract}

Keywords: External debt; Oil price; Exchange rate; Domestic savings; Nigeria

JEL Codes: F34

\section{INTRODUCTION}

External borrowing has been a major source of financial resources for developing countries to fill deficits gap between national savings and domestic investment. This means that the financial intermediations between the developing countries and the export credit agencies have improved the transfer of resources for future growth and sustainable development (Adamu and Rasiah, 2017; Adamu, 2016). For example, in the early period of independence, Nigerian economy was free from external shocks, and domestic economic policy responses were adjustable. The oil windfalls of the early 1970s brought huge foreign exchange earnings to Nigerian government. Government expenditure increased significantly and Nigeria used oil revenues as collateral and enjoyed credit ratings from export credit agencies as default was not anticipated (Lever and Huhne, 1985; Manzano and Rigobon, 2007). The collapse in the oil price in the early 1980s coupled with the sudden increase in international interest lending rate had a substantial negative impact on the Nigerian economy (Pinto, 1987; van Wijnbergen, 1984). Furthermore, exports of primary products and intermediate goods could not fill-in the declining foreign exchange earnings. The overvaluation of exchange rate drives import up, which aggravated the trade deficit and compelled Nigeria to further foreign borrowing. The policy response to the fall in oil revenues failed to address the fundamental problems facing the economy. The appropriate economic response should have been a decline in government spending, a nominal devaluation of the currency, and a decrease in real wages to increase competitiveness in the tradeable sector. The actual adjustment programme produces large current account balance, balance of payments 
deficits, and compressed foreign exchange reserves increased the external debt leading to recession (Adedeji and Handa, 2008). The spill-over effect was further external debt build up, which became detrimental to the Nigeria's growth prospects. Likewise, Nigeria's inability in meeting the debt service obligations increases the stock of external debt.

This paper seeks to investigate the key drivers of increasing external debt in an open economy Nigeria from 1970 through 2017. The paper provides three significant contributions. First, this is the first study to consider two impulse dummies to capture the effects of real exchange rate devaluation and the multi-lateral debt relief initiatives granted to Nigeria in 2005. Second, relatively few studies have investigated the drivers of increasing external debt in Nigeria, and those available are over a decade old and the results to date have been inconclusive (see for example Ajayi, 1991; Nyatepe, 1993; Edo, 2002). Third, we incorporate oil price in the debt model to find out whether an increase or decrease in oil prices played a significant role in explaining the behaviour of external debt in Nigeria. This variable has been neglected majorly in the empirical studies. Fourth, in terms of methodology, this study seeks employ Johansen and Juselius (1990) multivariate cointegration test. It is believed that Johansen and Juselius is superior for testing cointegrating relation because of its robustness in providing an asymptotically efficient maximum likelihood approach for detecting the number of cointegrating equations (Osterholm and Hjalmarsson, 2007), which is unlikely in both Engle and Granger (1987) and Pesaran et al., (2001) approach.

Following the introduction, the rest of the paper is organised as follows. Section 2 presents the trends of external debt in Nigeria. Section 3 explores the theoretical and empirical literature while section 4 presents the model and methodology of the study. Section 5 reports the empirical results and discussion of key findings. Lastly, the paper concludes and draws policy implications.

\section{NIGERIA'S EXTERNAL DEBT PROFILE}

The problem of external borrowing cannot be limited to a particular country, as there are numerous developing countries facing external debt issues because the majority of these countries rely substantially on external loans for development projects and deficit financing. Figure 1 presents the trend in external debt from 1970 to 2017. For instance, the external debt was not volatile and contracted at concessional interest rates from bilateral and multilateral sources with long periods of repayment, which stood at US\$0.8 billion. By 1978, owing to the global oil glut, which overstretched the government finances, it became inevitable to borrow to fill the declining oil revenues. This paved the way to Decree 30 of 1978, which permitted the government to borrow under the circumstances. In 1978, Nigeria contracted the first US $\$ 1$ billion loan called "Jumbo loan" from the international export credit institutions. By 1980, the outstanding external debt had reached US $\$ 8.9$ billion. Despite rescheduling in 1986, the principal amount and interest continued to mount, which further worsened the debt problem reaching a high of US $\$ 33.4$ billion in 1990. Much increase in the debt stock during the latter period were associated to the state of the Nigerian economy as there was a depreciation of the Naira and collapse in the world commodity price, especially oil. In addition, a sharp increase in the international interest lending rate and poor macroeconomic policy contributes to Nigeria's incapacity to meet the debt service

obligations. These placed enormous pressure on the country's foreign exchange and constrained 
the import of other inputs and capital goods for enhancing domestic production and eventually hampered investment and depressed economic growth (Ajayi, 1991).

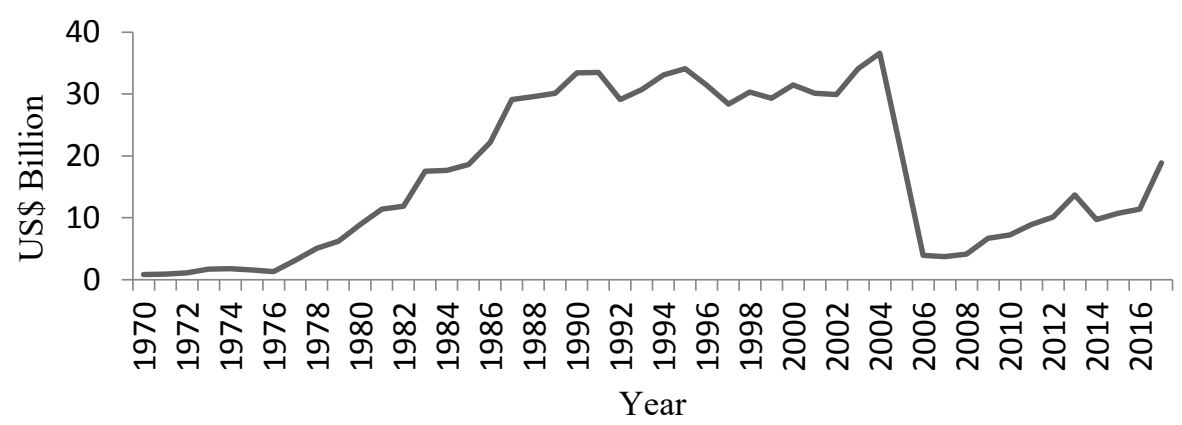

Figure 1: Trends in Total External Debt Stocks, 1970-2017

Source: World Bank, (2017), Debt Management Office (2017).

In 2000, the external debt stock stabilised to US\$30 billion due to the embargo imposed on new loans. The external debt further worsened reaching high to US\$36.6 billion as at 2004. Several factors contributed to the sharp rise of Nigeria's external debt. Among the notable macroeconomic variables include the rapidly increased in government spending, especially on developing infrastructure, external loans from export credit institutions at non-concessional interest rates, the collapse in the oil prices and greater reliance on imports. These factors contributed to the increasing trade arrears (Iyoha, 1999). This development led to the increased in debt service payments and worsened the external debt stock. This situation, no doubt, led to the country's frustration in meeting the debt service obligations that resulted in clamour in certain quarters for unilateral action against the creditor nations. On June 29, 2005, the Paris Club of creditors granted Nigeria a debt forgiveness or relief under the Multilateral Debt Relief Initiatives (MDRI) and Highly Indebted Poor Countries (HIPC's) (Adamu and Rasiah, 2016a). The terms of the agreement were a payment of arrears amounting to US\$6 billion based on the US\$30 billion of the Paris Club debt, and a stock reduction in Naples terms and buyback of the reminder for an automatic way out from the Paris Club creditors (DMO, 2013). Consequently, Nigeria benefited from a debt write-off of US $\$ 18$ billion. This considerably reduced the external debt from US $\$ 36.6$ billion in 2004 to US\$3.7 billion by 2006 as shown in Figure 1. Recently, there have been concerns about the rapid increase of external debt and its implications for the future growth and development, as the government resumes further borrowing reaching to about US\$18.9 Billion in 2017 (Adamu and Rasiah, 2017).

Table 1 reports the external debt and other economic indicators. As can be seen, the external debt as a percentage of GNI was very low in the early 1970s, from 7\% rose to 15\% between 1970 and 1980, and skyrocketed sharply to $120 \%$ in 1990 before dropping to $78.6 \%$ in 2000 and later fall drastically to $20.7 \%$ and 2.8 in 2005 following the debt relief granted to Nigeria by Paris club of creditors. The external debt service to export was $56 \%$ in the 1970 s rose to $227 \%$ by 1990 and declined steadily to about $9 \%$ in 2010 , and later increased to $36 \%$ by 2005 . The decline in the debt ratios was due to the debt relief earlier discussed. The annual GDP per capita in the early 1970s 
was growing at the rate of $22.2 \%$. The increase could be due to huge foreign earnings mainly from oil and gas related export revenues, which coincided with the oil boom of the fiscal year 1973/1974. The decline in the oil price from the late 1970s constituted an adverse impact on Nigeria's economic growth, which remained weak as the proceeds from the oil revenue fell drastically. This lowered the per capita GDP to less than $10 \%$ in 1990, and continue decline to a 1.8 in 2017 (World Bank, 2018). Furthermore, public investment deteriorated, for example, from $22.9 \%$ in 1970, it dropped to $16.8 \%$ in 1990 and grew steadily, except for 1990 that recorded $16.8 \%$, respectively (WMR, 2018).

Table 1: Nigeria's External Debt and Economic Indicators, 1970-2017

\begin{tabular}{lrrrrrrr}
\hline Indicator & 1970 & 1980 & 1990 & 2000 & 2005 & 2010 & 2017 \\
\hline External Debt (US\$bn) & 0.8 & 8.9 & 33.4 & 30.1 & 20.5 & 7.2 & 18.9 \\
Debt (\% of GNI) & 7 & 15 & 120 & 78.6 & 20.7 & 2.1 & 5.1 \\
Debt service (\%) & 56 & 32.1 & 227 & 149 & 36 & 8.8 & 45 \\
Oil price & 1.2 & 35.4 & 22.3 & 27.6 & 50.6 & 71.2 & 54.2 \\
Invest. (\% of GDP) & 22.9 & 27.4 & 16.8 & 7.2 & 8.1 & 16.9 & 15.7 \\
GDP per capita (\%) & 22.2 & 1.3 & 9.9 & 2.7 & 0.8 & 4.9 & -1.8 \\
\hline
\end{tabular}

Source: DMO (2018), OPEC (2018), World Bank Development Indicators (2018) and World Macroeconomic Research (2018).

Table 2 presents the composition of Nigeria's external debt by creditors. The breakdown indicates that out of the current total external debt stock of US $\$ 18.913$ billion, US $\$ 10.241$ billion, representing $54.2 \%$ was borrowed from multilateral creditors. This was followed by debt owed to commercial creditors US $\$ 6.300$ billion, representing $33.3 \%$, while bilateral debt all together accounted for only US\$2.372 billion representing $12.5 \%$, respectively.

Table 2: Nigeria's External Debt Stock by Creditors as at December, 2017

\begin{tabular}{lcc}
\hline Category & Balance outstanding $(\mathrm{US} \$ \mathrm{~m})$ & Percentage \\
\hline Multilateral & $10,241.00$ & 54.15 \\
Bilateral & $2,372.00$ & 12.54 \\
Commercial & $6,300.00$ & 33.31 \\
Total & $\mathbf{1 8 , 9 1 3 . 0 0}$ & $\mathbf{1 0 0 . 0 0}$ \\
\hline
\end{tabular}

Source: Debt Management Office, Nigeria (2018).

\section{REVIEW OF RELATED LITERATURE}

In this paper, we underpinned our analysis with two competing propositions "Dutch disease" and "Two-gap" models. It is called "Dutch disease" after the Netherlands poor record of utilising income from tradeable resources (oil and gas) in the 1960s, which led to the decline in the competitiveness of the tradeable goods and appreciation of real exchange rate (Corden and Neary, 1982; van Wijnbergen, 1984). They argued that excessive expenditure on consumption predicated on oil proceeds increases the demand for non-tradeable over the tradeable sectors, which draws productive resources into that sector. In contrast to the Dutch disease perspective, the two-gap model has been widely used to established that savings and investment constraints that slow down the future growth of many developing countries. Chenery and Bruno (1962) and Chenery and Strout (1966) argued that import of capital in the form of loans can assists in 
changing developing countries that are characterised by low savings, low investment leading to poor economic performance. Accordingly, developing countries suffer from foreign exchange gap and high fiscal deficit, which requires additional financial resources to fill the widening gap. This suggestion has been considered for accelerating economic performance in developing countries (Harberger, 1985; Solimano, 1993; Bacha, 1990; and Taylor, 1993).

However, empirical studies at the country level have produced mixed results despite a number of different methodologies, scope and period. For instance, Using descriptive analysis, Okoye (2000) analyse the causes of external debt in Nigeria and found that a poor productive base made the economy dependent on imports, had led to a considerable increase in import bills. The decline in foreign exchange earnings following the collapse in the oil prices in the early 1980s increased in the international interest lending rate, and huge expenditures on projects with zero economic viability have raised the Nigeria's external debt. In the same vein, Edo (2002) employ the ordinary least square method to investigate the rationale behind the external debt build up in Nigeria and Morocco over the period 1980 through 2001. The empirical results indicated that external factors such as interest rate, terms of trade and decline in the competitiveness of primary product have contributed to the accumulated external debt in both economies. In the same vein, institutional factors such as corruption and poor accountability, jointly with inflation, and terms of trade increased the stock of external debt in Nigeria.

Omotoye et al., (2006) use a multivariate model to examine the debt crisis in Nigeria and SubSaharan African countries from 1970 and 2001. The empirical results uncovered several factors such as poor leadership and political uprising, unfavourable terms of trade and privatisation are the most important factors explaining the debt crisis in Nigeria. In Jordan, Bader and Magableh (2009) deploy annual data from 1980 through to 2005 to estimate the contributing factors of public debt. Their findings indicate that huge budget deficit, real exchange rate appreciation and savings gap are the leading factors causing debt build up, but the real exchange rate is the most effective among all factors. Ogunmuyiwa (2011) explore the causal linkages between fiscal deficit and the external debt in Nigeria from 1970 to 2007. The study found no causal relation between the variables due to structural changes inherent in both fiscal deficit and the stock of external debt. Benedict et al., (2014) study the determinants of external debt spanning from 1986 to 2010 and found the real exchange rate, increasing debt service payments, and low output growth is the main contributing factors leading to the debt build up in Nigeria. They advocated for effective and efficient utilisation of external loans in viable, productive investment. Murwirapachena and Kapingura (2015) estimate a debt equation to determine the factors leading to the increase in South African external debt from 1980 to 2013. Using the VAR framework, they found that a decline in growth rate and increasing government expenditure on capital as the main factors causing external debt accumulation. In the case of Pakistan, Awan et al., (2015) investigate the macroeconomic determinants of increasing the stock of external debt over the period 1976 through 2010. The study concluded that trade openness, nominal exchange rate and the increasing government fiscal deficit played an important role in the external debt accumulation in Pakistan. Also, the study found foreign aid and terms of trade are with the stock of external debt but statistically insignificant. Adamu and Rasiah (2016b) conclude oil price, debt service, 
gross domestic savings and some macroeconomics indicators play a significant role in determining external debt in Nigeria.

Besides single country case, there are studies that focused on multi country case. For example, Anorou et al., (2006) estimate a panel data regression for 29 HIPCs of Sub-Saharan Africa from 1984 to 2000 and found that poor macroeconomic performance and institutional factors such as corruption, political instability, and the bureaucratic bottleneck are the major contributing factors of increasing external public debt in those countries. Using panel data for the Caribbean community over the 1987 to 2005 period, Greenidge et al., (2010) conclude that real effective exchange rate, decline in output, exports, disproportionate government expenditure, and real interest rate have been the major determinants of accumulated external public debt in the region. Tiruneh (2004) also conclude that debt service payments and capital flight are the major causes of foreign borrowing in developing countries. Savings gap and income instability are also the determining factors. He added that developing countries are heterogeneous in terms of colonial heritage, creditworthiness, and geopolitics is attributed to high levels of indebtedness. Blackmon (2014) examined the causes of the high percentages of developing countries' debt owed to governmental export credit agencies. He revealed that the debt owed to creditor institutions becomes a major cause in the long term debt problems of developing countries. It has been documented that Paris Club rescheduling and debt relief does not substantially ease the debt problems of these countries, instead they provide additional export credit loans and guarantees through their institutions in these countries, which eventually increases the debt burden.

\section{MODEL, DATA AND METHODOLOGY}

\subsection{Model and Data}

Following from the review of literature, the model framework to estimate the key drivers governing the accumulation of external debt in Nigeria is a replica of the model proposed by Greenidge et al., (2010) as follows:

$E_{t}=\delta_{t}+x_{t} \psi+\mu_{t}$

where $E_{t}$ is the total external debt (dependent variable), $\delta$ as the constant term of the model while $x$ is a vector of explanatory variables. Nonetheless, $\psi$ stand for the vector of the respective elasticities while $t$ and $\mu$ are time period and the stochastic error term to take care of unobserved variables in the model. The following debt function is specified.

$E_{t}=f\left(O_{t}, S_{t}, F_{t}\right)$

where $O_{t} S_{t} F_{t}$ denotes oil price, gross domestic savings and government fiscal deficit respectively. After transforming the variables into log form, equation (2) gives the following baseline regression equation. 
$\ln E_{t}=\delta_{0}+\delta_{1} \ln \left(O_{t}\right)+\delta_{2} \ln \left(S_{t}\right)+\delta_{3} \ln \left(F_{t}\right)+\mu_{t}$

Annual time series data spanning from 1970 to 2017 is employed, making a total of 48 observations. Data on external debt, gross domestic savings and government fiscal deficits as percentage of GDP are collected from the World Development Indicators, World Bank. While oil price is measured based on yearly brent crude oil spot price per barrel is obtained from Organization of Petroleum Exporting Countries (OPEC).

\subsection{Methodology}

Prior to empirical estimations, the stationarity of the variables have to be examined in order to identify their degree of integration. Two traditional unit roots are used, namely, the Augmented Dickey Fuller (Dickey and Fuller, 1981) and Phillips and Perron (1988) tests. For cointegration test, Johansen and Juselius (1990) multivariate cointegration test is used to examine the long run relationship among the variables $[E, O, S, F]$. This test involves two likelihood of the reduced rank of the $\Pi$ matrix, namely - the trace test $\left(\lambda_{\text {trace }}\right)$ and maximum eigenvalue test $\left(\lambda_{\max }\right)$, as shown in equation (4) and (5).

$$
\begin{aligned}
& \lambda \text { trace }=-T \sum_{i=r+1}^{n} \ln \left(1-\lambda_{i}\right) \\
& \lambda \max =-T \sum_{i=r+1}^{n} \ln \left(1-\lambda_{i}\right)
\end{aligned}
$$

where $T$ is defined as the sample size and $i \lambda$ is the $i$ th largest canonical correlation. The trace test is used in testing the null hypothesis of $r$ cointegrating vectors against the alternative hypothesis of $n$ cointegrating vectors. The maximum eigenvalue test, on the other hand, tests the null hypothesis of $r$ cointegrating vectors against the alternative hypothesis of $r+1$ cointegrating vectors.

Establishing a unique order of integration and cointegrating relation among the candidate variables implies a vector error correction model. The lagged residual, ect $t$ - derived from the cointegrating vectors is incorporated into the model. To estimate the parsimonious vector error correction model, the famous technique of general to specific (GETS) approach (Hendry, 1995) is employed. This is by removing the highest insignificant variable until a parsimonious short run model is attained. The vector error correction model is specified as follows:

$$
\begin{aligned}
& \Delta \ln \left(E_{t}\right)=\delta_{0}+\sum_{i=1}^{p} \delta_{1} \Delta \ln \left(E_{t-1}\right)+\sum_{i=0}^{p} \delta_{2} \Delta \ln \left(O_{t}\right)+\sum_{i=0}^{p} \delta_{3} \Delta \ln \left(S_{t}\right)+\sum_{i=0}^{p} \delta_{4} \Delta \ln \left(F_{t}\right) \\
& +\delta_{5}\left(D_{86 t}\right)+\delta_{6}\left(D_{05 t}\right)+\eta_{1}\left(e c t_{t-1}\right)+\mu_{t}
\end{aligned}
$$


where $\Delta$ is the first difference operator, $p$ is the lag length and $\delta_{i}$ are the coefficients to be estimated in the short run dynamics of the parsimonious error correction model, and ect $t_{\mathrm{t}-1}$ denotes the lagged error correction term generated from the preferred cointegrating vector. $t$ and $\mu$ are time dynamic and the Gaussian error term to capture unobserved variables in the model. Unlike in the long run equation, $D_{86}$ and $D_{05}$ are the two impulse dummies incorporated in the short run to account for exchange rate devaluation following the government economic reform introduced in 1986 and the debt relief in 2005 due to Highly Indebted Poor Countries (HIPCs) and Multilateral Debt Relief Initiatives (MDRI) declaration.

\section{RESULTS AND DISCUSSION}

Table 3 reports the results of the unit root tests for the four candidate variables using two different models with varying deterministic components. First, the model with the constant, which assumes no linear trends in the levels of the variable, such that the first differenced series have a zero mean i.e. model with a constant. Second, a model with a constant and trend that takes account of unknown exogenous growth. As can be seen from the results, log of external debt $\left(\ln E_{t}\right), \log$ of oil price $\left(\ln O_{t}\right), \log$ of domestic savings $\left(\ln S_{t}\right)$ and $\log$ of fiscal deficit $\left(\ln F_{t}\right)$ are not stationary at level, but becomes stationary after the first difference in both ADP and PP tests. Going by the results, it is concluded that all the four candidate variables have unique order of integration, i.e. they follow the $I(1)$ process.

Table 3: Unit root tests

\begin{tabular}{|c|c|c|c|c|c|}
\hline \multirow[t]{2}{*}{ Variable } & \multicolumn{2}{|r|}{$\mathrm{ADF}$} & \multicolumn{2}{|r|}{ PP } & \multirow{2}{*}{$\begin{array}{l}\mathrm{I}(d) \\
I(1)\end{array}$} \\
\hline & Level & First difference & Level & First difference & \\
\hline $\ln E_{t}$ & $-0.539[1]$ & $-5.192[1]^{* * *}$ & $-0.364[1]$ & $-7.210[1]^{* * *}$ & $I(1)$ \\
\hline $\ln O_{t}$ & $-0.621[1]$ & $-4.439[1]^{* *}$ & $-1.332[1]$ & $-4.764[1]^{* *}$ & $I(1)$ \\
\hline $\ln S_{t}$ & $-0.846[3]$ & $-6.873[0]^{* * *}$ & $-0.652[1]$ & $-6.920[1]^{* * *}$ & $I(1)$ \\
\hline $\ln F_{t}$ & $-1.123[2]$ & $-4.115[0]^{* *}$ & $-1.841[1]$ & $-4.093[1]^{* * *}$ & $I(1)$ \\
\hline
\end{tabular}

Establishing the order of integration, allow for Johansen-Iuselius cointegration test. Prior to that, an appropriate lag structure has to be identified since the Johansen cointegration test is sensitive to lag selection. The selection of lag order is conducted from a number of lag length criterion, namely, sequential modified test statistic of likelihood ratio ( $\log \mathrm{L})$, Likelihood ratio test (LR), Final prediction error (FPE), Akaike Information Criteria (AIC), Schwarz information criteria (SC) and Hannan-Quinn information criteria (HR). Table 4 reports the lag order selection from which the model with minimum value is to be chosen as the optimum lag length for the VAR model. 
However, except sequential modified test statistics of the likelihood ratio, all the criteria choses lag order one, and out of the six criteria final prediction error is chosen based on the minimum value of the test statistics.

Table 4: VAR Lag Order Selection Criteria

\begin{tabular}{cllllll}
\hline Lag & Log L & LR & FPE & AIC & SC & HQ \\
\hline 0 & -129.805 & NA & 0.008 & 6.527 & 6.694 & 6.587 \\
1 & -48.497 & $142.784^{*}$ & $0.000^{*}$ & $3.341^{*}$ & $4.177^{*}$ & $3.645^{*}$ \\
2 & -36.880 & 18.134 & 0.000 & 3.555 & 5.059 & 4.103 \\
3 & -27.454 & 12.873 & 0.000 & 3.875 & 6.049 & 4.667 \\
\hline
\end{tabular}

Note: ${ }^{*}$ indicates lag order selected by the criterion

Having identified the lag order, the Johansen cointegration test is conducted based on the maximum likelihood ratio using the five cointegration test specifications (Johansen and Juselius, 1995). This is to select an appropriate normalized cointegrating vector in accordance with the theoretical literature. Two exogenous zero-one step dummies are incorporated in the Johansen cointegration test in order to pick up the possible structural break. First, the exchange rate devaluation dummy $\left(D_{86}\right)$ that captures the impact of Nigerian economic reform policy tagged Structural Adjustment Program introduced in 1986. Second, the debt relief dummy (D05) to account for the Multilateral Debt Relief Initiative (MDRI) granted to Nigeria in 2005 by the Paris club creditors.

Table 5 presents the results of the Johansen cointegration test based on the two likelihood ratio teste i.e. trace and max-eigenvalue statistics. Results indicate cointegrating vectors at most one in both trace and max-eigenvalue statistics. This confirmed the existence of one cointegrating relationship among the four candidate variables. Of the five suggested cointegrating equations (CE's), only $\ln E_{t}$ (.) relation i.e. $\ln E_{t}-\ln O_{t}-\ln S_{t}-\ln F_{t}$ being considered for the analysis while the other four CEs are not the main focus of our study. At the lower segment of Table 5, the normalized cointegration coefficients are reported. Interestingly, all the estimated coefficients have their expected signs and statistically significant base on the a priori expectations as indicated by the $t$-statistics. The estimated coefficient of oil price $\left(\ln O_{t}\right)$ is ambiguous but appears to be 1.508 , negative and statistically significant at the $1 \%$ level. A $1 \%$ fall in the oil price is associated with the response of external debt by $1.5 \%$ increase. This implies that a fall in the oil prices signifies short in revenue which in turn creates a huge government deficit and compelled government to borrow in order to fill-in the financing gap. It is worth to note that over $90 \%$ of the Nigeria's foreign exchange earnings is fundamentally from oil export, which serve as a major source for funding government expenditure and there was no effective contingency plans for savings to bail the financial difficulties in the case of oil price crisis. This result coincides with the earlier findings by Okoye (2000) and Adamu and Rasiah (2016b) and the views of Corden and Neary, 1982 and Manzano and Rigbon (2007) respectively. 
Table 5: Johansen-Juselius multivariate cointegration test results-[E, $O, S, F]$

\begin{tabular}{lccccc}
\hline $\begin{array}{l}\text { Null } \\
\text { hypothesis }\end{array}$ & Eigen value & $-T \sum_{i=r+1}^{n} \ln \left(1-\lambda_{i}\right)$ & $\hat{\lambda} \max (0.05)$ & $-T \sum_{i=r+1}^{n} \ln \left(1-\lambda_{i}\right)$ & $\hat{\lambda}$ trace $(0.05)$ \\
\hline$r=0$ & 0.563 & $33.177^{*}$ & 27.07 & $62.445^{*}$ & 47.21 \\
$r \leq 1$ & 0.288 & 15.924 & 20.97 & 29.280 & 29.63 \\
$r \leq 2$ & 0.270 & 12.618 & 14.07 & 13.355 & 15.41 \\
$r \leq 3$ & 0.018 & 0.737 & 3.76 & 0.737 & 3.76
\end{tabular}

Long run normalized cointegrating equation:

$\begin{array}{llll}\ln E_{t}= & -1.508 \ln O_{t} & -0.208 \ln S_{t} & +0.253 \ln F_{t} \\ (0.333) & (0.120) & (0.126) \\ & {[-4.526]^{* * *}} & {[-1.734]^{* *}} & {[2.007]^{* * *}}\end{array}$

Note: Both trace and max-eigenvalue tests indicate one cointegrating equation at $5 \%$ significance level. Two zero-one dummy variables $\left(D_{86}\right.$ and $\left.D_{05}\right)$ are incorporated as the exorgenous variables in the estimation. Figures in bracket and square bracket are standard errors and $t$-statistics.

The coefficient of gross domestic savings is -0.208 , negative and statistically significant at the $5 \%$ level. A $1 \%$ decrease gross domestic savings rate will result to a higher rate of external debt approximately by $0.21 \%$. This suggests that inadequate savings lead to financial difficulties, since savings has been considered as a tool for macroeconomic stability and promote development. The inadequate domestic savings rates had forced the nation to borrow more, which eventually, aggravates the stock of external debt. This finding is in line with the study of Okoye (2000). Also, it is conform to a priori expectation of the theoretical analysis of the capital accumulation theory championed by Chenery and Strout, (1966) among others. The coefficient of the government fiscal deficit $\left(\ln F_{t}\right)$ is 0.253 , positive and statistically significant at the $1 \%$ level. A $1 \%$ increase in the fiscal deficit worsens the Nigerian external debt position by $0.25 \%$. The increase in the fiscal deficit could be due to many factors. For example, Nigeria's extra budgetary activities in which the government expenditure outweigh the expected revenue, and in most cases not appropriately utilized. As a result, government resorts to borrowing in order to finance the unprecedented deficit, which directly increases the debt stock. This finding coincides with the view of Bacha, (1990) and Tailor (1993).

Table 6 reports the short run dynamic model. Maximum lag orders of five were considered. After a series of eliminations, lag orders of three are appropriate for the parsimonious short run model. Interestingly, the results obtained are in accord with the normalized cointegrating vector. All the estimated coefficients are statistically significant at the conventional levels. The coefficients oil price, gross domestic savings and government fiscal deficit have the reasonable size and magnitude, though, long run coefficients are relatively larger than the short run. 
Table 6: Parsimonious Vector Error Correction Model dependent variable $-\ln E_{t}$

\begin{tabular}{|c|c|c|c|c|}
\hline Variable & Coefficient & Std.Error & $\mathrm{t}$-Statistics & Prob. \\
\hline$\Delta \ln E_{t(-1)}$ & -0.178 & 0.132 & -1.346 & 0.191 \\
\hline$\Delta \ln E_{t(-2)}$ & $-0.388^{* * *}$ & 0.125 & -3.092 & 0.005 \\
\hline$\Delta \ln O_{t}$ & $-0.337^{* * *}$ & 0.116 & -2.900 & 0.008 \\
\hline$\Delta \ln O_{t(-3)}$ & -0.098 & 0.065 & -1.491 & 0.149 \\
\hline$\Delta \ln S_{t(-3)}$ & $0.174^{* *}$ & 0.077 & 2.253 & 0.033 \\
\hline$\Delta \ln F_{t}$ & $0.340^{* * *}$ & 0.048 & 6.950 & 0.000 \\
\hline$\Delta \ln F_{t(-3)}$ & 0.096 & 0.059 & 1.627 & 0.117 \\
\hline$D_{86}$ & $-0.107^{*}$ & 0.062 & -1.732 & 0.096 \\
\hline$D_{05}$ & $0.254^{* *}$ & 0.102 & 2.469 & 0.021 \\
\hline ect $t-1$ & $-0.044^{*}$ & 0.025 & -1.774 & 0.089 \\
\hline$R^{2}$ & 0.810 & & & \\
\hline Adjusted $R^{2}$ & 0.694 & & & \\
\hline$F$-statistic & $7.013^{* * *}$ & & & \\
\hline$D W$ & 2.033 & & & \\
\hline Diagnostic check & & \multicolumn{3}{|c|}{$F$-statistics [ $p$-value] } \\
\hline$\chi^{2}$ SERIAL (1) & & $0.3240[0.7$ & & \\
\hline$\chi^{2} N O R M A L$ & & $0.2264[0.4$ & & \\
\hline$\chi^{2} A R C H(3)$ & & $0.6722[0.3$ & & \\
\hline$\chi^{2}$ RAMSEY (1) & & $0.1283[0.2$ & & \\
\hline CUSUM and CUSUMSQ & & Stable & & \\
\hline
\end{tabular}

Notes: ${ }^{* * *},{ }^{* *}$ and ${ }^{*}$ indicate $1 \%, 5 \%$ and $10 \%$ level of significance. Figures in bracket $(\ldots)$ and square bracket $[\ldots]$ are the lag selected and the $p$-values.

The estimated coefficient of the dummy for exchange rate devaluation $\left(D_{86}\right)$ that captures government economic reform policy introduced in 1986 is -0.107, negative and statistically significant at the $10 \%$ level. A $1 \%$ point change in exchange rate (devaluation) leads to a significant increase in external debt approximately by $0.11 \%$. This suggests that the more the exchange rate devaluation, the higher the external debt since the domestic currency (i.e. Nigerian Naira) losses its value to foreign currency, notably US dollar or pound sterling. Similarly, it may 
cause contractionary effect via external debt whereby the Naira losses its value and increase the debt service payments. This implies that the government economic reform policy championed by the World Bank and International Monetary Fund (IMF) had contributed significantly to the external debt accumulation in Nigeria. For example, in 1980, debt ratios were $32 \%$ and $15 \%$ of the country's exports and GDP. By 1990, both ratios reached $227 \%$ and $120 \%$ of Nigeria's exports and GDP. However, following the debt relief package, Nigeria's debt ratios declined drastically to $6 \%$ and $3 \%$ of the exports and GDP in 2006. Meanwhile, the decision by Nigeria to continue external borrowing at the peak of exchange rate crisis results to a serious effect on the stock of external debt in the country. In a nutshell, exchange rate devaluation has been a core factor among the determinants of external debt in Nigeria.

The coefficient of the dummy variable for debt relief $\left(D_{05}\right)$ is 0.254 , positive and statistically significant at the 5\% level. A $1 \%$ increase in resources freed as a result of debt relief influences external debt borrowing approximately by $0.25 \%$. Although, the provision of debt relief to highly indebted poor countries by the multilateral debt relief initiatives reduced the rate of inflation, but provide an opportunity for government to increase public sector budget as a result the fiscal adjustment remain unsuccessful as the demand for more external debt increases. This indicates that debt relief granted by the Paris club creditors in 2005, made Nigeria to be creditworthy, and open the chance for the government to re-borrow, in which the external debt reached US $\$ 18.913$ billion in 2017 from US\$3.7 billion in 2006. This finding is consistent with the view Tiruneh (2004) that debt reduction brought an insignificant benefit to the debtor countries as the debt reduction or forgiveness has paved the way for the beneficiary countries to seek for fresh loans corresponding to the sum of debt reduction to overcome capital deficiency, until they restored the previous net worth, and back to heavily indebted countries.

The error correction term (ect t-1) is -0.044 , negative and statistically significant at the $10 \%$ level. This finding further confirmed the existence of a co-integrating relation among the respective variables under investigation. It also indicates that the speed of adjustment toward the long run equilibrium after a shock to the system will be corrected by $0.04 \%$ in a year. The diagnostic tests are presented in the lower segment of Table 5. The result suggests that no serial correlation and the Jaque Bera test of the estimated residuals are normally distributed. The autoregressive conditional heteroscedasticity and Ramsey RESET tests confirmed that the estimated model is correctly specified with no misspecification problem. In addition, the CUSUM and CUSUMSQ for stability test (Brown et al., 1975) indicates that the short run model is stable since the recursive residual indicated by a band line is within the boundaries.

\section{Conclusion}

This paper investigates the key drivers leading to an increase in external debt in Nigeria over the period 1970 to 2017. After examining the stationarity of the variables, Johansen multivariate cointegration test is applied to establish the long run cointegrating relationship among the variables. The empirical result confirms a unique cointegrating relationship. The estimated normalized long run and short run coefficients are according to the theory deliberated in the literature. The two zero-one impulse dummy variables incorporated in the short run model were found to be statistically significant. This implies that all the variables are important 'drivers' for increasing external debt in Nigerian. 
In the light of our findings, the following policy implications are offered. First, Nigeria should focus on investment in real sectors, especially in agriculture and manufacturing to increase export performance. This can enable the country to generate adequate foreign earnings and stimulate domestic savings, and reduce dependence on oil revenue and high demand for external loans. Second, deficit financing through external borrowing increases the stock of external debt, however, government should curtail unnecessary spending because records have shown that a substantial portion of the borrowed fund were spent on unproductive investment. Therefore, improving sources of government income through a simplified tax base structure, in conjunction with the reduction or total shift from overemphasizing on Keynesian view of fiscal stabilization through deficit spending would reduce the high deficit and the increasing tendencies for government borrowing.

\section{References}

Adamu, I.M. (2016). Public Investment in Nigeria. Does External Debt Matter? Academic Journal of Economic Studies, 2(4), 120-138.

Adamu, I.M., \& Rasiah, R. (2016a). External debt and growth dynamics in Nigeria. African Development Review, 28(3), 291-303.

Adamu, I.M., \& Rasiah, R. (2016b). On the determinants of external debt in Nigeria. Available at SSRN 2865568.

Adamu \& Rasiah (2017). Domestic investment, External debt and Economic growth: Cointegration and Causality Evidence from Nigeria. Journal of Contemporary Issue and Thought, 7 (1), 1 - 9.

Adedeji, O.S. \& Handa, J. (2008). The Size and Sustainability of the Nigerian Current Accounts Deficits. The Journal of Developing Areas, 41 (2), 1-25.

Ajayi, S.I. (1991). Macroeconomic Approach to External Debt: A case study of Nigeria. African Economic Research Consortium (AERC) (Research Paper No. 8). Nairobi: Kenya.

Anorou, E., Dimkpah, Y. \& Ahmad, Y. (2006). Dynamics of External Debts among HIPC Countries. Journal of International Business Research, 5(1), 41-52.

Awan, R.U., Anjum, A., \&v Rahim, S. (2015). An econometric analysis of determinants of external debt in Pakistan. British Journal of Economics, Management and Trade, 5(4), 383-391.

Bacha, E. L. (1990). A Three-gap Model of Foreign Transfers and the GDP growth in Developing Countries. Journal of Development Economics, 32, 279-296.

Bader, M., \& Magableh, I. K. (2009). An enquiry into the main determinants of public debt in Jordan: An econometric study. Dirasat: Administrative Sciences, 36(1), 181-190.

Benedict, I.B., Ehikioya, I.L., \& Asin, M.O. (2014). Determinants and sustainability of external debt in a deregulated economy: A cointegration analysis from Nigeria (1986-2010). American International Journal of Contemporary Research, 4(6), 201-214.

Blackmon, P. (2014). Determinants of developing country debt: the revolving door of debt rescheduling through the Paris Club and export credits. Third World Quarterly, 35(8), 1423-1440.

Brown, R.L., Durbin, J. \& Evans, J.M. (1975). Techniques for testing the constancy of regression relationships over time (with Discussion). Journal of the Royal Statistical Society, 37, 149-192.

Chenery, H.B. \& Bruno, M. (1962). Development Alternatives in an open economy: The case of Israel Economic Journal, 72, 79-103.

Chenery, H.B. \& Strout, A. (1966). Foreign assistance and economic development. American Economic Review, 56(4), 679733.

Corden, W.M. \& Neary, J.P. (1982). Booming sector and de-industrialization in a small open economy. Economic Journal, $92,825-848$. 
Debt Management Office. (2018). Nigeria's Debt Relief deal with the Paris club. [Online] Available: www.dmo.gov.ng/debtrelief/resources/nigdebtreldeal.pdf.

Dickey, D.A. \& Fuller, W.A. (1981). "Likelihood Ratio Statistics for Autoregressive Time Series with a Unit Root". Econometrica, 49(4), 1057-1072.

Edo, S.E. (2002). The external debt problem in Africa: A comparative study of Nigeria and Morocco. African Development Review, 14(2), 221-236.

Engle, R.F. \& Granger, C.W.J. (1987). Co-integration and Error Correction: Representation, Estimation, and Testing. Econometrica, 55 (2), 251-276.

Greenidge, K., Drakes, L. \& Craigwell, R. (2010). The external debt in the Caribbean Community. Journal of Policy Modeling, 32, 418-431.

Harberger, A.C. (1985). Lessons for debtor-country managers and policy makers. In G.W. Smith and J. T.Cuddingto (ed) Internationational Debt and Developing Countries. IBRD, Washington, D.C.

Hendry, D.F. (1995). Dynamic econometrics. Oxford University Press on Demand.

Iyoha, M.A. (1999). External Debt and Economic Growth in Sub-Saharan Africa Countries. An Econometric Study (AERC Research Paper No. 90-1999). African Economic Research Consortium, Nairobi, Kenya, p. 1-53.

Johansen, S. \& Juselius, K. (1990). Maximum likelihood estimation and inference and cointegration with application to the demand for money. Oxford Bulletin of Economics and Statistics, 52, 169-2010.

Lever, H. \& Huhne, C. (1985). Debt and danger: The world financial crisis. London: Penguin books Ltd.

Manzano, O. \& Rigobon, R. (2007). Resource curse or debt overhang? Chapter 3 in D. Lederman and W.F. Maloney (eds), Natural resources: Neither curse nor destiny (41-70). Stanford University Press. The World Bank.

Murwirapachena, G. \& Kapingura, F.M. (2015). Determinants of external debt in South Africa: a VAR-based approach. International Journal of Economic Policy in Emerging Economies, 8(2), 138-152.

Nyatepe-coo, A.A. (1993). External disturbances, domestic policy responses and debt accumulation in Nigeria. World Development, 21(10), 1621-1631.

Ogunmuyiwa, M.S. (2011). Does External Debt Promote Economic Growth in Nigeria? Current Research Journal of Economic Theory, 3(1), 29-35.

Okoye, E.I. (2000). The Nigerian debt problem: causes and consequences and policy option. African Banking and finance Review, 1(1), 57-64.

Omotoye, R., Hari, S., Christopher, N., \& Maxwell, E. (2006). Sub-Saharan Africa's debt crisis: Analysis and Forecast based on Nigeria. Emerald Managerial Finance, 32(7), 606-620.

Organization of the Petroleum Exporting Countries (OPEC), Database (2018)

Osterholm, P. \& Hjalmarsson, E. (2007). Testing for cointegration using the Johansen methodology when variables are nearintegrated (No. 7-141). International Monetary Fund.

Pesaran, M.H., Shin, Y. \& Smith, R.J. (2001). Bounds Testing Approaches to the Analysis of Level Relationships. Journal of Applied Econometrics, 16, 289-326.

Phillips, P. \& Perron, P. (1988). Testing for a Unit Root in Time Series Regression. Biometrica, 75(2), 335-346.

Pinto, B. (1987). Nigeria During and After the Oil Boom: A policy Comparison with Indonesia. The World Bank Economic Review, 1(3), 419-445.

Solimano, A. (1993). Debt cisis, Adjustment Policies and Capital Formation in Developing Countries: Where Do We Stand? World Development, 21(1), 127-140.

Taylor, L. (1993). Gap models. Journal of Development Economics, 45, 17-34.

Tiruneh, M.W. (2004). An Empirical Investigation into the Determinants of External Indebtedness. (PRAGUE Economic Papers, 3). University of Munich, Munich, Germany.

van Wijnbergen, S. (1984). The Dutch Disease: A disease after all. The Economic Journal, 94, 41-55.

World Bank, World Development indicators, Database (2018).

World Macroeconomic Research, Database (2018). 